\title{
Strategic Options for Automobile OEMs of Indian Origin to have Sustained Competitive Advantage: A Case of Tata Motors
}

\author{
Shivakumar S. Malagihal ${ }^{1}$ (D)
}

Received: 25 March 2021 / Accepted: 2 July 2021 / Published online: 2 August 2021

(c) Global Institute of Flexible Systems Management 2021

\begin{abstract}
The competitive landscape of automobile original equipment manufacturers around the globe is continuously changing, with new business models impacting the performance of automobile firms. The study uses benchmarking technique to benchmark Tata Motors passenger vehicle segment performance with a relevant foreign passenger vehicle manufacturer to explore the differences in core capabilities and platform strategies. The gaps reveal that there is tough competition among the firms in the automobile industry in India. The study also uses the problem structuring method to structure the key problem of Tata Motors' inadequate leverage of product platforms and identify the high potential root causes. The findings reveal that strategic options such as proper management of employees at top leadership positions, technologies, and strategic cooperation with partner firms may help Tata Motors better leverage new modular platforms. The new strategic options may also provide possibilities to scale internationally in niche vehicle product segments to achieve sustained competitive advantage. Among several potential capabilities and resources analyzed, only a few seem to be transferable to leverage advanced modular platforms and related digital technologies for Tata Motors.
\end{abstract}

Keywords Automobile OEMs $\cdot$ Passenger vehicle segment $\cdot$ Strategic options $\cdot$ Platform approach $\cdot$ Sustained competitive advantage

\section{Introduction}

The automobile industry in India is an emerging and promising industry (Pillania, 2008; Sushil \& Garg, 2019) that contributes $7.1 \%$ towards India's GDP and accounts for $4.3 \%$ of the total exports (Invest India, 2020). Due to the rapidly increasing demand, the automobile industry acts as an essential economic growth driver (MHIPE, 2012). Over the three decades, the Indian automobile industry has shown remarkable resilience to economic uncertainties; for example, Tata Motors Ltd has shown good recovery over the years and has registered impressive growth figures in the recent past. In India, the automobile industry, particularly the passenger vehicle business, was earlier dominated by local firms like Hindustan motors and Premier. However, after the liberalization in 1991, the Indian passenger vehicle market was flooded with foreign brands such as Suzuki,

Shivakumar S. Malagihal

204270008@iitb.ac.in

1 Shailesh J. Mehta School of Management, IIT Bombay, Powai 400076, Mumbai, India
Hyundai, and Toyota, who set up their facilities in India and offered models at competitive prices. The foreign brands dominated the market and created an intensely competitive business environment for traditional firms of Indian origin, such as Tata Motors, Mahindra and Mahindra Limited, and Ashok Leyland.

The growing economy and supportive demographic factors in India played an important role in making it an attractive automobile destination. According to the economic times auto (2018), only 22 people out of 1000 own a car in India, indicating a massive growth opportunity for India's automobile manufacturers. However, this opportunity to leverage domestic players' growth potential comes with the significant challenge of facing tough competition from multinational auto companies (Singh et al., 2007). These include Hyundai Motors, Maruti Suzuki, and others. This competition has increased pressure on firms of Indian origin (FIOs) to manufacture high-quality vehicles at a lower cost and manufacture different car models in a shorter lead duration (Scavarda et al., 2009; Singh et al., 2007). Today, FIOs have adequate reserves, but they seem to have inadequate technological capabilities and limited in-house expertise 
(Saad \& Patel, 2006; Singh et al., 2007). To address these challenges, automobile FIOs have to improve their competitiveness and business performance by developing various sources of competitive advantage (Fig. 1), such as advanced technological capabilities with effective business strategies to avail the existing and future business opportunities.

The study intends to identify the potential sources of competitive advantage for the Tata Motors passenger vehicle segment in the digital economy. The sources are classified based on the Asset-Processes-Performance (APP) framework (Ambastha \& Momaya, 2004), as shown in Fig. 1. Among these three facets of competitiveness, the competitiveness process and performance facets are the prime focus of this study. The product platform strategy is common across several industries. A few examples of successful product platforms are Volkswagen's vehicle modular platform (Lampón et al., 2017), Intel's chip platform (Cusumano \& Gawer, 2002), and HP's printer platform (Meyer \& Lehnerd, 1997). In the long run, the product platform strategies seem to reduce production costs and increase product variety, helping firms gain a competitive advantage (Seyoum \& Lian, 2018). Therefore, to investigate the potential capabilities of an already established automobile OEM, this research focuses on the following research questions: How do modular platforms act as a new strategic option to improve Tata Motors' domestic and international competitiveness? Which critical resources can help Tata Motors to sustain its competitive advantage in the digital economy?

\section{Literature and Conceptual Background}

This section presents brief literature on past studies related to the competitiveness of automobile firms in India. Appendix SA1 in the supplementary file highlights all the working definitions of key concepts used in this paper. The literature reviewed is summarized very briefly in two sub-sections below.

\section{Competitiveness of Automobile Manufacturing Firms in India}

With globalization, automobile manufacturers have made numerous efforts to foster their competitiveness in the domestic and international markets. As a result, there is extensive research on multinational automobile manufacturers' competitive strategies from developed and developing nations (Freyssenet, 2009; Kalogerakis et al., 2017; Loganathan, 2013; Tambade et al., 2019). Most of the past studies have highlighted several findings on factors (Table 1) that impact the automobile industry's competitiveness.

Scholars have also explicitly discussed the various priorities and factors contributing to car manufacturers' improved competitiveness in India. For example, in India, Nauhria et. al. (2011) listed the essential competitive priorities: consumer perspective, quality, and cost. Innovation and product technology as the following critical factors. However, the role of technology advancement (Umamaheswari \& Momaya, 2008) and new platforms and digital technologies and platform capabilities to gain competitive advantage are less studied.

\section{Strategic Management of Technology as an Option to Improve Competitiveness and Business Performance}

Technology is also considered an essential competitive factor at the firm level. Some scholars believe strategic technology management is a crucial practice to improve automobile OEMs (e.g., Maruti Suzuki) competitiveness (Sahoo et al., 2011), and techniques such as SAP-LAP (Sushil, 2009) were used to analyze the organization. Several researchers have studied the case of Tata Motors in recent times (Alagappan et al., 2013; Becker-Ritterspach \& Bruche, 2012; Sushil \&
Fig. 1 Indicative sources of competitiveness for PV automobile OEMs, their relevance and performance. Source: author's compilation based on the adaptation of Momaya, (2001) and Ambastha and Momaya (2004)

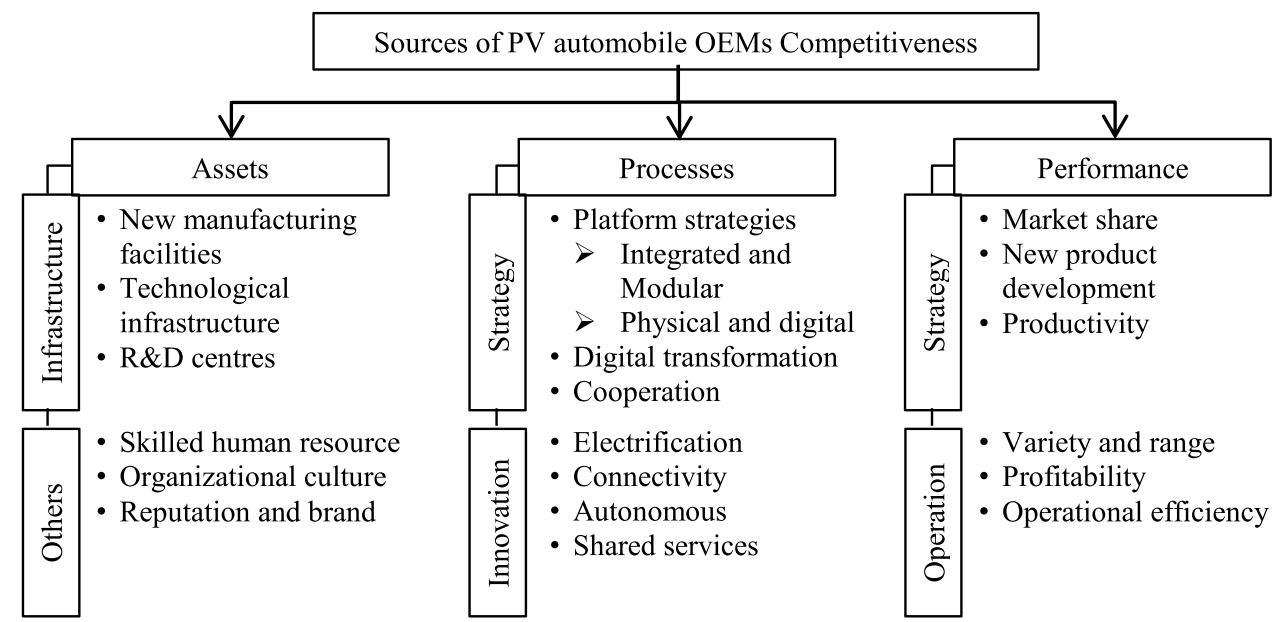


Table 1 Some recent studies on factors that contribute to the competitive advantage of automobile firms in India

\begin{tabular}{lll}
\hline Attributes & Factors & Authors \\
\hline Assets & Technology, physical infrastructure, raw materials & Nauhria et. al. (2018) \\
Processes & Radical innovations & Kumar and Subrahmanya (2010) \\
& Digitalisation, process innovations & Kalogerakis et. al. (2017) \\
& Process innovation & Kalogerakis et. al. (2017) \\
& Internationalization & Sushil and Garg (2019) \\
& Policymaking toward EV & Pahurkar and Metha (2017) \\
Performance & Market share gain, customer satisfaction, better & Alagappan et. al. (2013) \\
& capacity utilization, and high productivity & \\
\hline
\end{tabular}

Attributes classified as per competitiveness Assets, Processes, Performance (APP) framework (Momaya, 2001)

Source: Author's compilation
Garg, 2019). Becker-Ritterspach and Bruche (2012) focused on capability creation and internationalization of Tata Motors with the help of its business group; Alagappan et. al. (2013) highlight marketing strategy as one of the critical factors for competitive advantage. The study by Sushil and Garg (2019) attempts to list down and analyze some of the strategic options adopted by Tata Motors to manage the changing forces in the automobile industry. However, these studies focused very little on the progress of Tata Motors in leveraging technologies related to modular platforms as a strategic option for sustained competitive advantage (Bannasch et al., 2017).

\section{Methodologies and Data}

\section{Methodologies}

Among several frameworks of competitiveness, the ones that leverage benchmarking are considered better for exploratory studies. For example, the competitiveness Assets-ProcessesPerformance (Competitiveness APP) framework (Momaya, 2001; Ambastha \& Momaya, 2004) allows extensive use of benchmarking (from quick benchmarking to detailed) at factor and criteria levels in phases such as diagnostics of problem, gap identification, and trend analysis. Another simple competitiveness framework ABCD tested in Indian contexts (e.g., Momaya, 2019; Moon et al., 2015) gives perspectives on benchmarking. So we have benchmarked TATA Motors passenger vehicle segment performance with leading passenger vehicle manufacturers in India and globally. The benchmarking approach enabled us to explore the differences in technological capabilities and platform strategies adopted by other leading firms in India.

We conducted this study in three steps. First, we evaluate Tata Motors' performance by benchmarking its key strengths, market share, R\&D spend, the number of patents filed, vehicle modular platform initiatives, and other financial parameters with global top-performing automobile OEM.

In the second step, we attempt to structure the critical problem and determine the root causes using the problem structuring method (Momaya et al., 2016). The complete description of the problem structuring method is given in the supplementary file Appendix SA2.

In the third and final step, the study attempts to identify and evaluate Tata Motors' critical resources and capabilities, including platform related, to explore how Tata Motors can engage in the platform economy to climb up the value curve (Umamaheswari \& Momaya, 2008). The combination of benchmarking technique, problem structuring, and critical resource identification technique helped us analyze the performance gaps and platform capabilities among two plus one case organizations (the third case comparison can be seen in the supplementary file). This approach added strength to the research findings, although the nature of the data collected did not permit us to use any statistical technique. Despite several limitations, the study identified some exciting results that are different from previous studies' findings.

\section{Data Collection and Analysis}

In the first step, we collected data from secondary sources such as annual reports of select companies, literature, published articles, company websites, news media articles, and stories published by automobile associations (International council of clean transportation and the Society of Indian Automobile Manufacturers). In the second and third steps, we collected inputs through informal and structured interactions with the automobile industry to evolve better root causes and critical resource lists. Finally, we analyzed the qualitative and quantitative data collected from various sources and derived our findings and inferences based on the patterns and trends that emerged from the data. 


\section{Case Study of Tata Motors}

Tata Motors is one of the leading international automobile manufacturers, part of the Tata group's multinational conglomerate. Tata Motors was incorporated on September 01, 1945, headquartered in Mumbai, India (Tata Motors Website, 2021). Tata Motors is listed on the Bombay Stock Exchange (BSE) and National Stock Exchange (NSE). Tata Motors is part of the Fortune Global 500 list. It has come a long way on a sustained international competitiveness journey by launching new innovative products and expanding into international markets, e.g., through Jaguar Land Rover's acquisition (JLR). Its product variants include passenger vehicles, commercial vehicles, and defence vehicles. Tata Motors' success in select segments is mainly supported by its ability to leverage technology and well-managed cooperative relationship to develop innovation capabilities (Bruche, 2010). Tata Motors, a market leader in the commercial vehicle segment, also managed to 'Leapfrog' to the passenger vehicle segment (Becker-Ritterspach \& Bruche, 2012). Tata Motors leads the domestic market commercial vehicle segment with a 37\% market share in 2019-2020 (Bloomberg, 2021). It has its manufacturing units in Lucknow, Dharwad, Pune Jamshedpur, Pantnagar, and Sanand in India. It also has marked its global presence by establishing manufacturing plants in the U.K., South Korea, Thailand, South Africa, Indonesia, Austria, and Slovakia.

Tata Motors also has been in the passenger car market for over two and half decades. Over the years, it has launched classic indigenous vehicles such as the Tata Indica, Tata Sumo, Tata Safari, and the Tata Nano. However, TML's business in the passenger vehicle segment has remained relatively weak for many years due to increasing domestic competition from international auto manufacturing firms such as Hyundai Motors, Volkswagen, and Maruti Suzuki (Bodhanwala \& Bodhanwala, 2020). TML's passenger vehicles (PV) business dropped to $5.7 \%$ in 2018 from its $15 \%$ share in 2008 , as shown in Figs. 2, 3. Tata Motors is also not present in every car segment (refer to Table SA3.7 in supplementary file) and has limited product variants indicating its growth opportunities in many other categories.

In 2017, the Chairman of Tata Sons, Natarajan Chandrasekaran, expressed his concern over the losses in Tata Motors' passenger car segment and its cost structures are out of whack. Every car and model at Tata Motors was losing money, and the chairman highlighted the importance of picking up volumes to become profitable (Taumar, 2017).

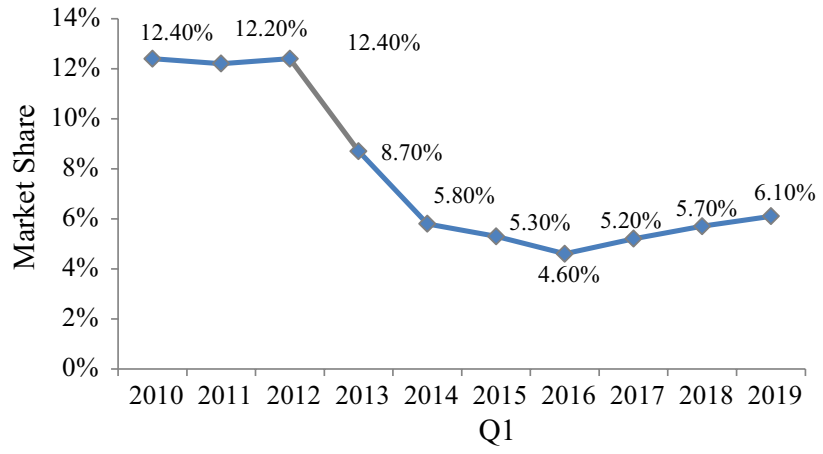

Fig. 3 Tata Motors market share in the passenger vehicle segment, FY 2010-FY Q1 2019. Source: created by Author based on the data from Tata Motors Investors Resources-Investing in Tata Motors (https://www.tatamotors.com/investors/download-library/)
Fig. 2 Market Share of automobile companies in the passenger car segment in India (FY 2008 and 2018). Source: SIAM, India Brand Equity Foundation (2008); International council on clean transportation (2020). Passenger vehicle market size (2018): Approx. 4 Million; Source: SIAM

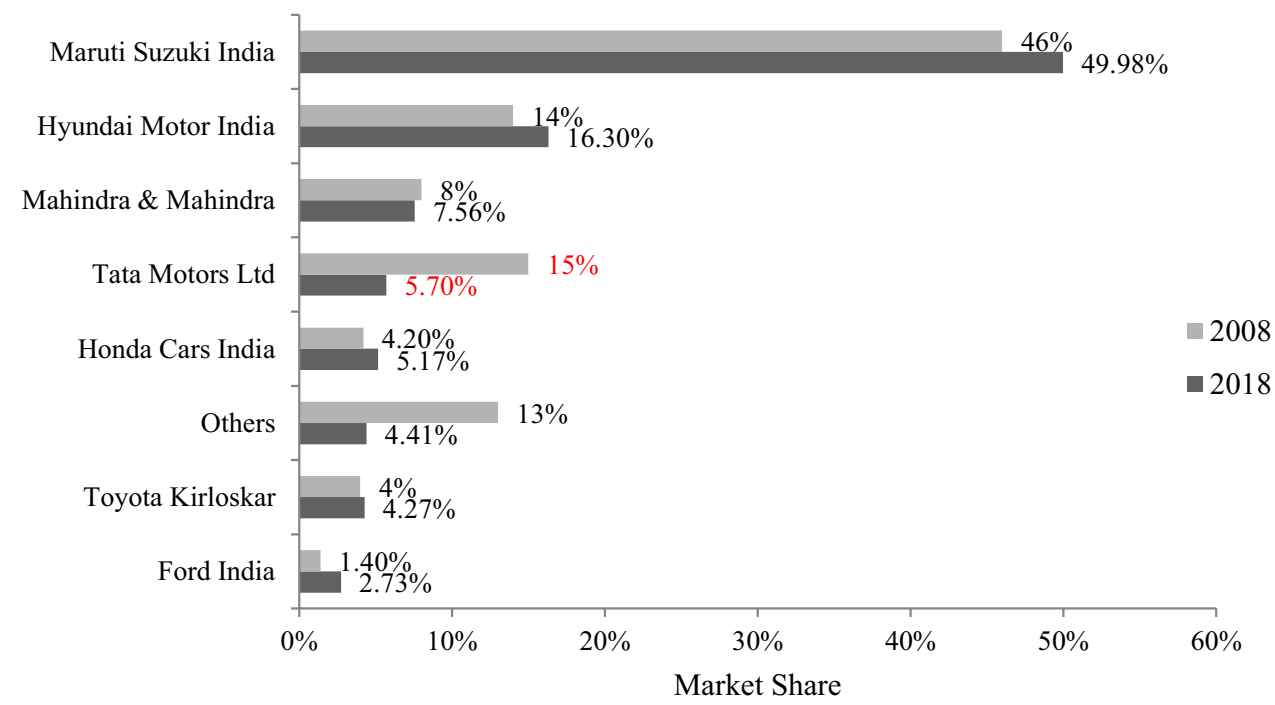




\section{Emerging Findings from the Comparative Analysis Study}

\section{Indicative Findings from Quick Benchmarking Tata Motors with Hyundai Motors Company}

While Maruti Suzuki India limited holds the maximum share in the Indian passenger segment (India Brand Equity Foundation, 2021), Hyundai Motors Company (HMC), which has entered India in 1996, has progressed well in a short period. An initial literature review and a quick benchmarking with Hyundai Motors provided brief insights into Tata Motors Limited's (TML) gaps; Table 2 provides a glimpse. TML's inadequate leverage platforms (e.g., modular platforms and digital platforms) to enhance its domestic and international competitiveness is a significant problem to be studied. In addition, TML's considerable loss in the passenger vehicle segment's domestic market share over the years, as discussed earlier, and its slow strategic decision-making ability to address the problem seems to be a significant competitiveness dilemma. Appendix A Tables 6, 7, 8 exhibit the quick benchmarking between Tata Motors and Hyundai Motors India (India market).

The overall financial condition of Tata Motors has underperformed (e.g., Net income, EBITDA) compared to Hyundai Motors India and has relatively low ROIC (return on invested capital) growth (Appendix A Table 8). In the last 5 years, Hyundai's better performance (domestic and international markets) can be attributed to its increasing employee productivity, as shown in Fig. 4.

Table 2 Brief introduction of comparison firms Tata Motors and Hyundai Motors India

\begin{tabular}{lll}
\hline About & Tata Motors & Hyundai Motors India \\
\hline Establishment year & 1945 & 1967 \\
Parent company & Tata Group & Hyundai Motor Company \\
Headquarter & Mumbai India & Seoul, South Korea \\
PV segment entry (India) & 1991 & 1996 \\
Approx. Total PV sales so far (2021) & $40,00,000$ & $1,00,00,000$ \\
Number of manufacturing facilities in India (PV) & 4 & 2 \\
Number of R\&D centers & 2 & 1 \\
Current car models in India(2021) & 6 & 10 \\
Service points in India & 8400 (PV +CV) & 1309 \\
Number of segments present in & Cars and Sports Utility Vehicles Trucks and & Cars and Sports Utility Vehicles \\
Patents granted (2010-2020) & Buses, Defence & 28,002 \\
Patents related to platforms & 131 & 235 \\
\hline
\end{tabular}

$P V$ Passenger Vehicle

Source: company websites, espacenet patents

Fig. 4 Employee productivity (domestic and international markets) of TML and HMC. Source: Refinitve database

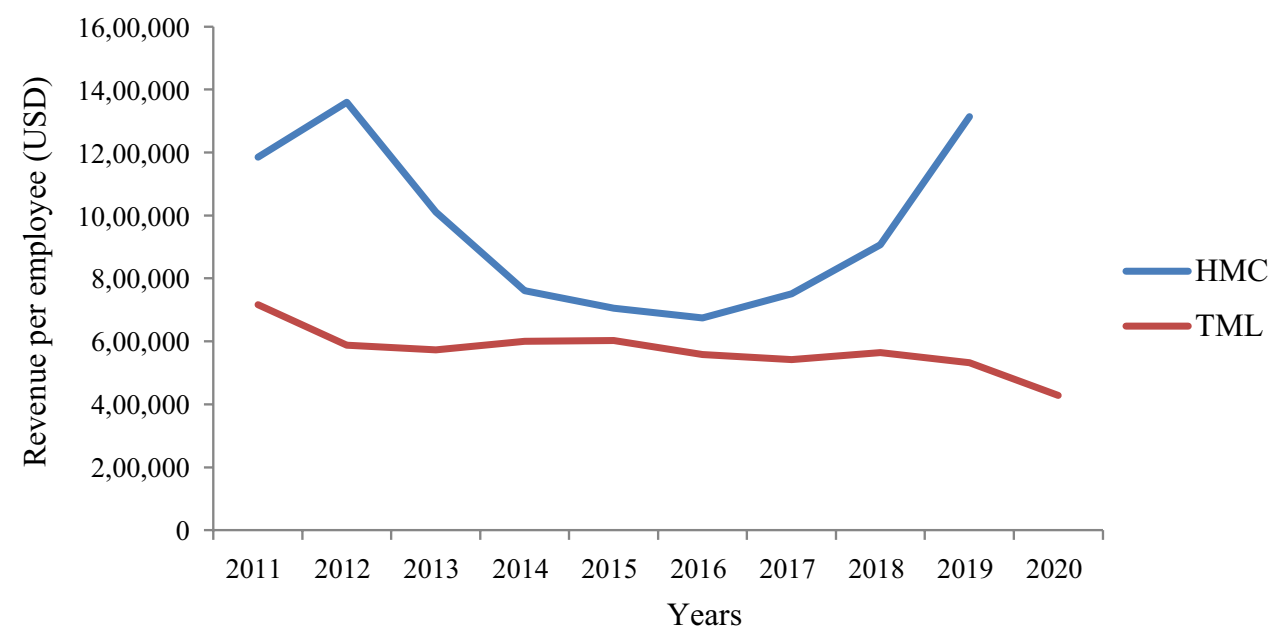




\section{Indicative Findings from a Detailed Comparison of Select Companies-Passenger Vehicle Segment}

Hyundai's capabilities include having superior physical and digital infrastructure with high availability and excellent customer interfaces well-established standards to build good relationships with consumers on new digital channels such as online sales and social media platforms. On the other hand, Tata Motors has come a long way in the Indian automobile industry since 1945 and is still experiencing slow growth in its product portfolio in the domestic market. As shown in Fig. 5, Tata Motors' PV business focus has remained domestic, and the domestic market is smaller (4 million, SIAM) than other western markets. Tata Motors has focused significantly less on exports and has diminishing export values than Hyundai Motors India, as shown in Fig. 6. Tata Motors has $60 \%$ market coverage in various segments, focusing on positioning itself in the growing SUV segments. Tata Motors has not shown interest to cater its vehicles in all the available passenger vehicle segments (refer to Table SA3.7 in supplementary file).

The Indian automobile major Tata Motors is years behind when it comes to using advanced technologies compared with leading international automobile manufacturers. This section also addresses Tata Motors' inadequate leverage of new platform approaches to improve its domestic and international competitiveness in the passenger vehicle segment. Hyundai's ability to leverage platforms (Table 3) and other advanced automobile digital technologies (Table 4) may have helped HMC to achieve a sustainable competitive advantage in the Indian automobile market. For cost innovation, HMC also plans to adopt new global modular electric vehicle architecture to enhance the efficiency and scalability of product development. For example, Hyundai has a new E-GMP platform that will underpin future Hyundai, Kia, and Genesis models.

On the other hand, Tata Motors' current passenger vehicles are built on four platforms Tata X1, Super Ace, Modular platforms (Alfa and Omega), and it plans to make all its vehicles on Alfa and Omega. Moreover, in response to the COVID-19 pandemic, car OEMs have launched their online sales platforms. For example, 'ClicktoDrive' by Tata Motors and 'Clicktobuy' by Hyundai Motors India. The new online sales platforms have integrated more than 600 dealer outlets across India (Tata Motors news, 2020; Hyundai Motors press, 2020).

\section{How may new Platforms help Tata Motors in Gaining a Sustained Competitive Advantage?}

Although the strategic investment decision to reduce the number of vehicle platforms was taken in 2013, Tata Motors took more than seven years to launch their first modular platform (e.g., advanced modular platform in 2020).

Post the modular platform release, Tata Motors is able to climb up to the third position in passenger vehicle sales for the financial year 2020-21 (Tata Motors annual analyst engagement report, 2021). The company posted sales of 1.65 lakh units of PVs in FY20-21, a growth of 66\% from the 2019 financial year sale values as shown in Fig. 7, but

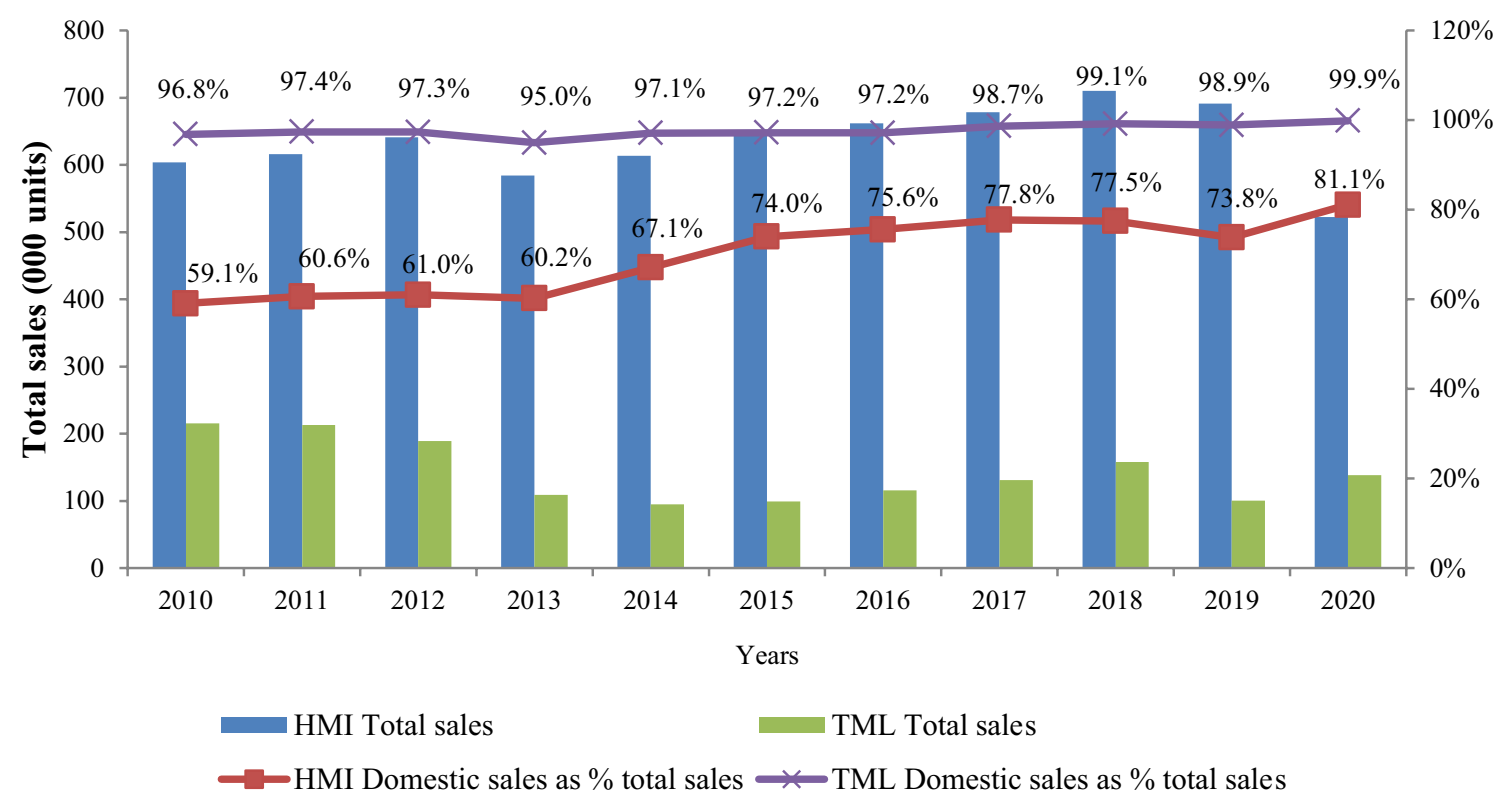

Fig. 5 Passenger vehicles (cars) domestic sales as \% of total sales (domestic and export). Source: TML and HMI sales webpage. Note: HMIHyundai Motors India; TML: Tata Motors Limited 


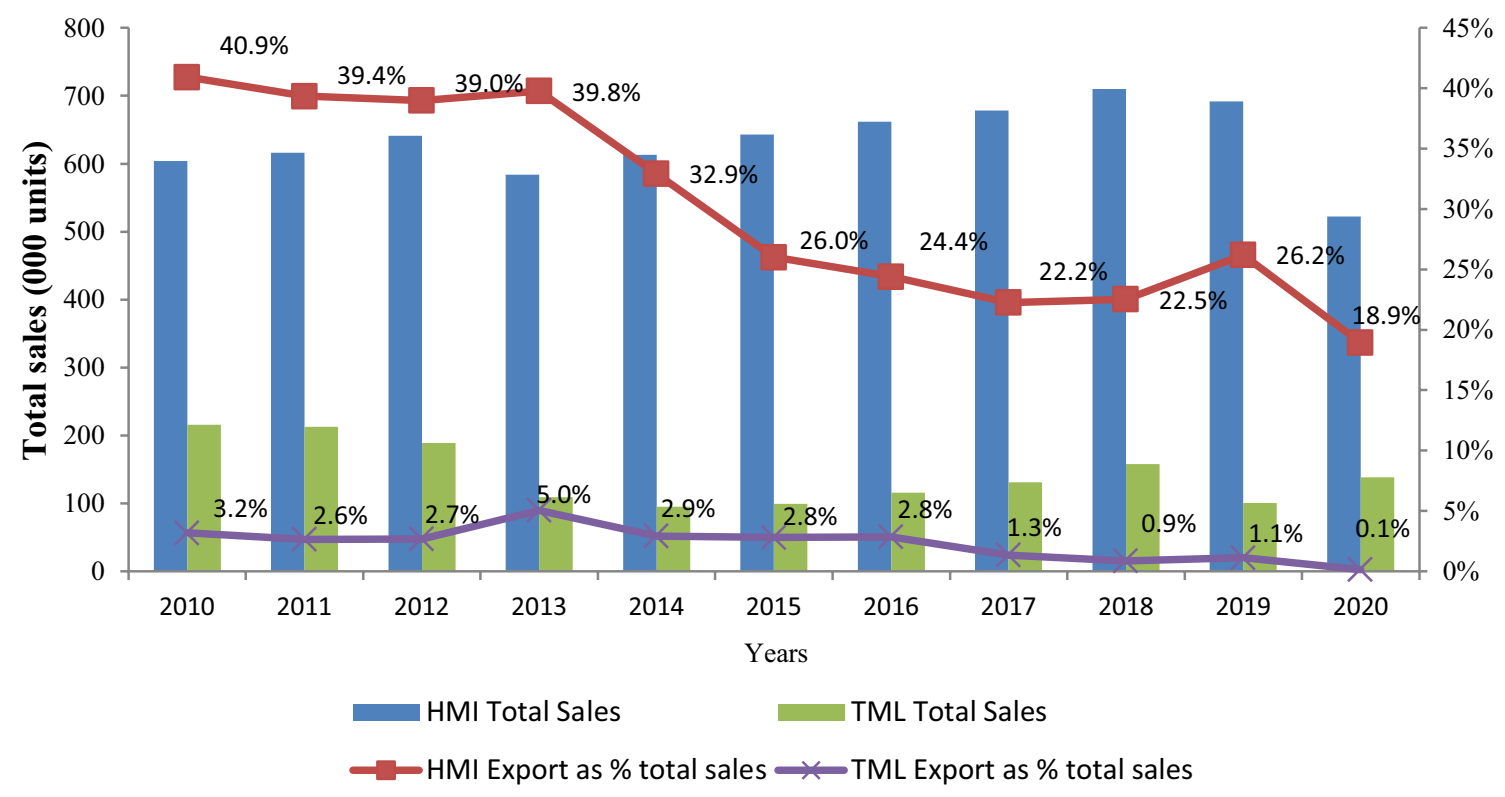

Fig. 6 Passenger vehicles (cars) exports numbers as \% of total sales (domestic and export). Source: TML and HMI sales webpage. Note: HMIHyundai Motors India; TML: Tata Motors Limited

the company is still making losses on its passenger segment (Appendix A Table 6).

\section{Summary Findings from Problem Structuring}

The initial benchmarking exercise with Hyundai Motors Company provided an idea about Tata Motors Limited's passenger vehicle segment gaps. Inadequate leverage of new platform approaches to improve its competitiveness in the passenger vehicle segment is a significant problem for Tata Motors. Some critical competitiveness dilemmas are decreasing passenger vehicle market share in India and the low ability to leverage its long legacy brand value in India. While its commercial vehicle segment is a leader in the domestic market, its passenger vehicle segment's contribution to achieving a sustainable competitive advantage is questionable. The study attempts to structure the relatively less addressed Tata Motors passenger vehicle segment's inadequate leverage of new platform approaches to enhance its overall competitiveness. The actor-based root cause analysis (Momaya et al., 2016) helped us identify the potential actor-based root causes for the problem identified. The study revealed that all the identified five actors (refer to blue line box in Fig. 8) contribute equally to the problem identified.

The reasons associated with Tata Motors' top management team of the passenger vehicle segment, more specifically the frequent exit of top leaders in the PV segment and unwillingness to adopt new business models, emerged as the primary root cause for the problem identified. Followed by this, the decision of the government of India to implement
BS-VI by skipping the BS-V increased the spending of Tata Motors to adhere to BS-VI norms. Overall, top leaders' strategic investment decision ability and the production and design capabilities of Tata Motors are causing the inadequate leverage of the product platform approach as a new strategic option to improve domestic and international competitiveness. The study indicates that Tata Motors may need to focus on agility and its cultural change to adapt new models and efficiently leverage the modular platform approach to create more growth opportunities.

\section{Evaluation of Tata Motor's Critical Resources and Capabilities}

In this section, the study attempts to leverage the resourcebased view (Barney, 1991) to analyze Tata Motors Limited's resources (Table 5) that are valuable, rare, inimitable, and organizational-oriented. We have established a list of approximate resources and capabilities based on our interaction with the highly experienced experts (Castanias \& Helfat, 1991) from academia and the automobile industry.

Tata Motor's decision to focus on developing the advanced modular platforms and product sequencing capabilities seems to provide an opportunity to improve its economies of scale and scope, reduce development timelines, and improve sustainability. Tata Motors can strengthen its technological capabilities with its advanced modular platforms, such as connected vehicle technology and digital platforms. Tata Motor's sister firms, such as Tata Consultancy Services, Tata Communications, and Tata Technologies, can help develop cloud-based 


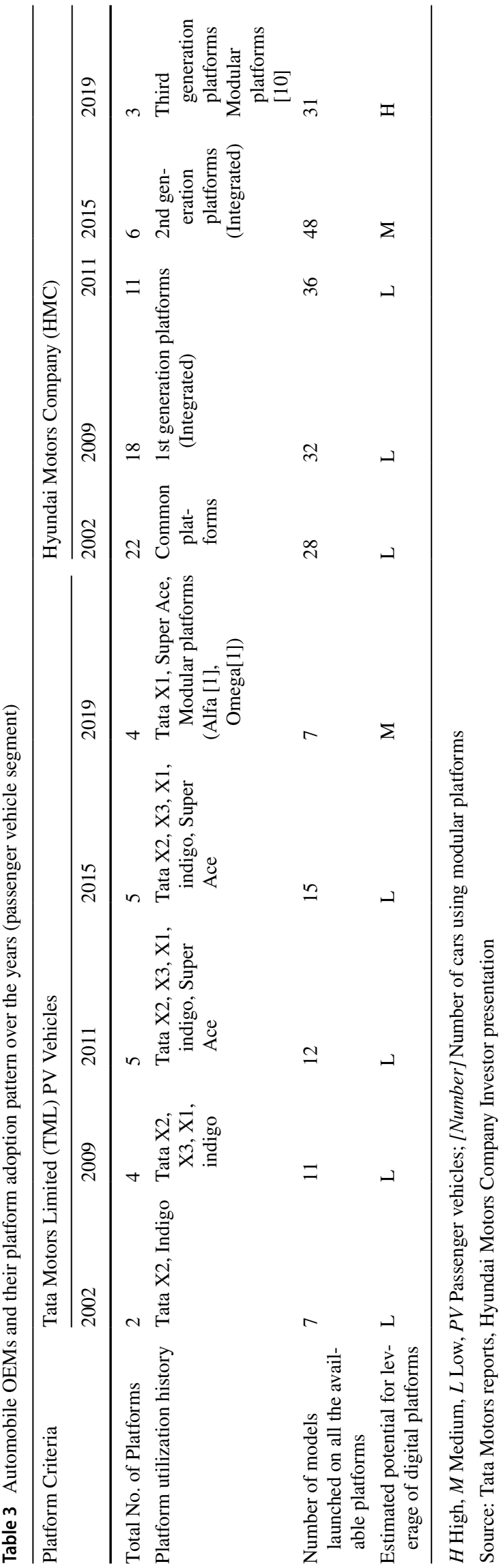

Table 4 Adoption of digital platform approach by select automobile OEMs (Passenger vehicle segment)

\begin{tabular}{lll}
\hline Online sales platform & Tata Motors PV & Hyundai Motors India \\
\hline Online platform name & Clicktodrive & Clicktobuy \\
Launch year & Apr-20 & March 20 \\
Home delivery & Yes & Yes \\
Integrated dealers & 750 & 600 \\
Online car booking & NA & 1900 \\
March-July 2020 & & \\
Visitors & $40 \%$ of total Tata & 1.5 Million \\
& Motors custom- & \\
& ers & 20,000 \\
Online registered cus- & NA & \\
tomers (March-July & & \\
2020) &
\end{tabular}

Source: Clicktodrive website, Clicktobuy website, (Dhingra, 2020)

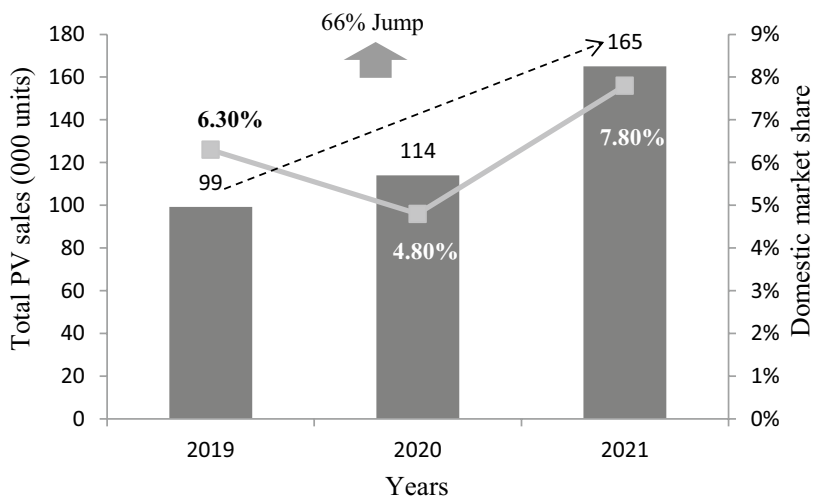

Fig. 7 Tata Motors PV volumes launched on new platforms (launched from 2019). Source: Tata Motors annual analyst engagement report 2021

IoT platforms, connectivity technologies, and data management (Tata review, 2020). Focus on standardization and decentralization of its operations may help the firm reduce operating costs and improve its production efficiency. Utilizing its existing research and technology capabilities may also help the firm develop future-ready innovative products (Sushil \& Garg, 2019).

Another critical resource that can provide high value to customers is its online sales digital platform called 'Click to Drive.' The online digital sales platform helps automobile OEMs and dealers to improve customer engagement even after sales (Tata Motors Press, 2020). 


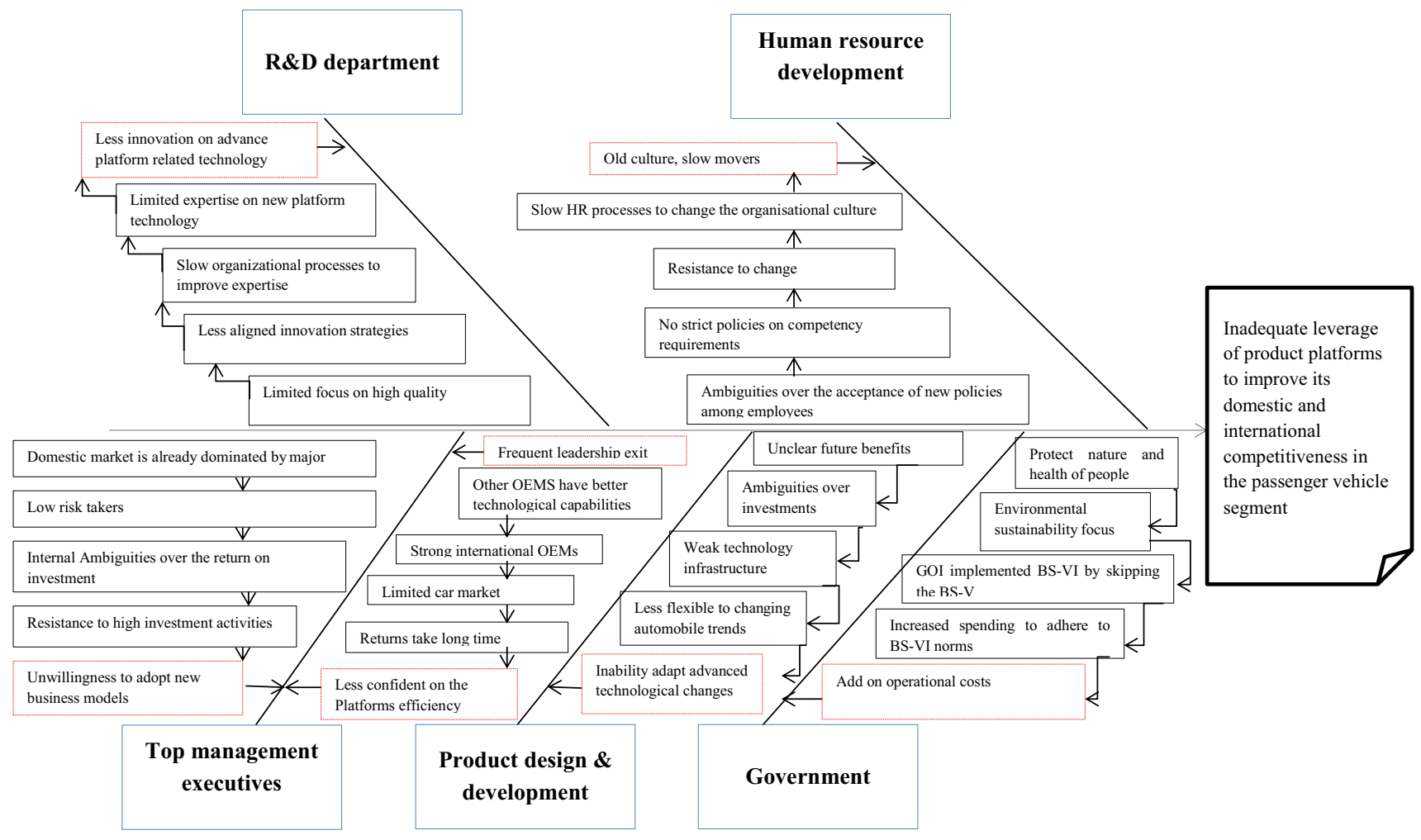

Fig. 8 Indicative Root Cause Analysis (RCA) Diagram. Note: Red doted boxes are high potential causes identified (scored above seven). Refer to Table SA3.11 in the supplementary file

\section{Conclusions and Implications}

Automobile OEMs worldwide, such as Volkswagen, Volvo, and BMW, are early adapters to modular platforms (Lampón et al., 2019). However, OEMs from Asia are slow in leveraging modular platforms and their associated digital technology advantages. Asian automobile OEMs seem to have started developing modular platforms, particularly for passenger vehicles launched on electric vehicle (EV) platforms (e.g., Hyundai Motors E-GMP and Tata Motors' electric vehicle modular platform). These electric vehicle platforms have better engine and transmission sub-platform, where electronics content is much higher, and there is potential for data collection. For automobile manufacturers OEMs, achieving economies of scale enhances their competitiveness in new product development and production systems (Haugh et al., 2010). In addition, standardizing the components and having a more significant number of standard units per automobile platform leads to economies of scale (Becker \& Zirpoli, 2003). Hence, modular platforms can be considered an option among automobile OEMs to achieve a competitive advantage.

Effective utilization of reserves, efficient management of digital technologies, and better leverage of its research and development capabilities can help Tata Motors to sustain its competitive advantage in the digital economy. Among several potential capabilities and resources analyzed, only a few seem to be transferable to leverage advanced modular platforms and related digital technologies for Tata Motors. Accordingly, the sustainability of competitive advantages of Tata Motors in segments related to new modular platforms and digital platforms seems low.

Tata Motors has been in the Indian passenger vehicle market for over two and half decades. It seems to have started focusing on leveraging the modular platform approach. Tata Motors currently has developed two modular platforms: Alfa and Omega modular platforms. The firm plans to place all its new car models on these two platforms to improve its economies of scale. Still, the pace of adopting new modular platforms to gain economies of scale and scope is languid as compared to Hyundai Motors and western automobile OEMs.

Moreover, adopting modular platforms demands more capital investments to develop new production facilities (Lampón et al., 2019). Still, Tata Motor may explore ingenious adaptation and technology absorption for specific new product development to reduce risks (Momaya, 2018). Hence, Tata Motors may have to make crucial strategic investment decisions before it is too late. 
Table 5 Assessment of Tata Motors' capabilities with potential for sustainable competitive advantage using VRIO (Passenger vehicle segment)

\begin{tabular}{|c|c|c|c|c|c|c|}
\hline Resource/Capability (incl. experience) & Value & Rarity & Inimitability & $\begin{array}{l}\text { Org } \\
\text { Exploit- } \\
\text { able }\end{array}$ & $\begin{array}{l}\text { Strength } \\
\text { of } \\
\mathrm{CA}(40)\end{array}$ & Remarks \\
\hline $\begin{array}{l}\text { Platform development and Product sequenc- } \\
\text { ing }\end{array}$ & 9 & 8 & 7 & 6 & 30 & $\begin{array}{l}\text { The efficient utilization of advanced modular } \\
\text { platforms is a challenge for Tata Motors as } \\
\text { it operates in a highly competitive market } \\
\text { (India) }\end{array}$ \\
\hline Domestic Network of firms in India & 9 & 8 & 6 & 5 & 28 & $\begin{array}{l}\text { Tata Motors has a strong network of five sub- } \\
\text { sidiaries and four associate companies }\end{array}$ \\
\hline $\begin{array}{l}\text { Cooperative strategies with sister firms } \\
\text { including TCS }\end{array}$ & 8 & 8 & 7 & 6 & 29 & $\begin{array}{l}\text { Tata Motors is among a few firms with sister } \\
\text { firms leading technology firms (e.g., Tata } \\
\text { Elxsi, Tata Communications, and TCS) }\end{array}$ \\
\hline International operations & 8 & 3 & 3 & 6 & 20 & $\begin{array}{l}\text { Tata Motors PV business majorly focused } \\
\text { on the domestic market and less on exports } \\
(<2 \%)\end{array}$ \\
\hline Digital platform (online sales platform) & 6 & 6 & 5 & 7 & 24 & $\begin{array}{l}\text { It is easier for OEMs to develop an online } \\
\text { sales platform and customers still prefer to } \\
\text { visit retail shops }\end{array}$ \\
\hline $\begin{array}{l}\text { Standardization and decentralization in } \\
\text { operations }\end{array}$ & 9 & 8 & 6 & 4 & 27 & $\begin{array}{l}\text { Manufacturing operations at the leading } \\
\text { international OEMs (Hyundai, BMW, and } \\
\text { Volkswagen) are standardized to reduce cost } \\
\text { and improve productivity }\end{array}$ \\
\hline $\begin{array}{l}\text { Manufacturing facilities / Established } \\
\text { Infrastructure }\end{array}$ & 7 & 4 & 4 & 7 & 22 & $\begin{array}{l}\text { Tata Motors can leverage its existing facilities } \\
\text { to improve its production capacity. Tata } \\
\text { Motors has state-of-the-art manufactur- } \\
\text { ing facilities at Chikhali, Pune; Sanand in } \\
\text { Gujarat }\end{array}$ \\
\hline $\begin{array}{l}\text { Existing research and technology capabili- } \\
\text { ties }\end{array}$ & 8 & 6 & 5 & 6 & 25 & $\begin{array}{l}\text { Limited utilization of its investments in } \\
\text { research and development to provide } \\
\text { improved variants continuously over time } \\
\text { is reflected in its limited number of patents } \\
\text { and new product launches }\end{array}$ \\
\hline Connected Vehicle Platform capability & 8 & 6 & 6 & 6 & 26 & $\begin{array}{l}\text { International OEMs show superior technolog- } \\
\text { ical capabilities that invest better in people, } \\
\text { research and development, and technology } \\
\text { partnerships }\end{array}$ \\
\hline
\end{tabular}

CA Competitive advantage

Source: Authors compilation, TATA Motors Annual reports, websites, experts from industries

Key questions that emerged in the problem structuring method areas follows:

1. What are the possible opportunities in the electric car segment for TATA Motors in the domestic and international market?

2. What segments of a passenger vehicle or mobility platform shall Tata Motors focus on for profitable growth in India and select international markets?

The proximate implications for automobile firms of Indian origin in passenger vehicle manufacturing seem to be precise. The platform modular approach and leveraging digital platforms can be a valuable option to consider. New platform options may help OEMs of Indian origin to catch up fast with other international OEMs. Cooperative strategies with matching partners (e.g., Momaya, 2009) can become important for such catch-up. Firms of Indian origin (FIOs) have strategic choices about cooperating with start-ups, ventures, or large firms in India, Asia, or the West. Careful decisions based on strategic insights can shape their future.

The paper's contribution is in using a detailed benchmarking technique that highlights the importance of leveraging capital-intensive modular platforms adequately by automobile firms in India to attain sustained competitive advantage. The study also contributes to 'characterizing the modular platform phenomenon' using the problem structuring' approach (Momaya et al., 2016). After multiple interactions with automobile industry experts (details provided in the supplementary file Table SA3.8), we identified the potential root causes for the problem statement ('EYE' of the root cause diagram). Finally, the study also contributes to 
theory by considering modular platforms as distinct strategic resource thinking in the competitive advantage research using tools such as VRIO.

\section{Limitation and Future Research}

Finally, this study has several limitations. First, the number of cases compared is small, and OEMs in India are still in their early stages of leveraging new platform approaches. Once Indian OEMs advance further, it would be advisable to confirm the findings of this study.

Although some firms such as Hyundai seem to be shifting towards modular platforms in later generations, creating a competitive advantage for FIO can be difficult in modular platforms (particularly against Chinese firms with more significant economies). Understanding what balances between modular vs. integrated, physical vs. digital platforms that help FIOs gain competitive advantage can be a valuable topic to study. Management of Technology (MoT; see Momaya, 2018) can be another high potential research area for international competitiveness. It can involve technology foresight to identify and invest in high-potential segments of greener mobility.

\section{Key Questions Reflecting Applicability in Real Life}

1. How do you connect your functional area (e.g., operations, finance, technology management, or HR) with the international competitiveness of the firm of your choice?

2. How can the problem structuring method be used to structure the critical problems in real-life organizations?

3. How can firms with limited platform capabilities sustain competitive advantage?

4. What balances between modular vs. integrated, physical vs. digital platforms can help FIOs gain international competitive advantage?

\section{Appendix A}

Additional tables related to quick benchmarking
Table 6 Key domestic (India) financial data of Tata Motors Ltd for cars and utility vehicles (Rs million)

Table 7 Key domestic (India) financial data of Hyundai Motors India for cars and utility vehicles (Rs million)

\begin{tabular}{lccccccc}
\hline Financial (Rs million) & Mar-20 & Mar-19 & Mar-18 & Mar-17 & Mar-16 & Jump & \% Jump \\
\hline Net sales & $4,34,855$ & $6,87,652$ & $5,74,409$ & $4,36,509$ & $4,23,426$ & 11,429 & 2.7 \\
Other operating income & 9,394 & 10,593 & 13,904 & 7119 & 5001 & 4393 & 87.8 \\
Total Operating Revenue & $4,44,248$ & $6,98,245$ & $5,88,312$ & $4,43,628$ & $4,28,427$ & 15,821 & 3.6 \\
Total cost of sales & $4,41,701$ & $6,40,329$ & $5,46,367$ & $4,28,6664,01,155$ & 40,546 & 10.4 \\
EBITDA & 2,548 & 57,915 & 41,946 & 14,962 & 27,271 & $(24,723)$ & -91 \\
OPBT & $(50,932)$ & 8981 & $(6527)$ & $(30,641)$ & $(11,941)$ & $(38,991)$ & - ve \\
PBT & $(71,304)$ & 23,989 & $(9469)$ & $(24,208)$ & $(598)$ & $(70,706)$ & - ve \\
PAT & $(72,927)$ & 20,206 & $(10,349)$ & $(24,800)$ & $(623)$ & $(72,304)$ & - ve \\
\hline
\end{tabular}

Source: CRISIL research

\begin{tabular}{lllllllll}
\hline Financial (Rs million) & Mar-20 & Mar-19 & Mar-18 & Mar-17 & Mar-16 & Jump & \% Jump \\
\hline Net sales & $4,40,074$ & $4,43,022$ & $3,70,460$ & $3,48,545$ & $3,13,898$ & $1,26,17640$ \\
Other operating income & 10,373 & 11,026 & 8976 & 10,598 & 8503 & 1870 & 22 \\
Total operating revenue & $4,50,447$ & $4,54,048$ & $3,79,436$ & $3,59,143$ & $3,22,401$ & $1,28,046$ & 40 \\
Total cost of sales & $4,06,868$ & $4,05,341$ & $3,35,104$ & $3,16,767$ & $2,90,498$ & $1,16,370$ & 40 \\
EBITDA & 43,579 & 48,707 & 44,331 & 42,376 & 31,904 & 11,675 & 37 \\
OPBT & 25,900 & 33,335 & 27,725 & 26,958 & 18,080 & 7820 & 43 \\
PBT & 32,372 & 39,678 & 32,414 & 29,695 & 18,795 & 13,577 & 72 \\
PAT & 23,550 & 25,817 & 21,242 & 19,729 & 12,910 & 10,640 & 82 \\
\hline
\end{tabular}

Source: CRISIL Research 
Table 8 Key metrics comparison of Tata Motors and Hyundai Motors India for Indian Market

\begin{tabular}{lcccccc}
\hline Criteria of competitiveness & Mar-16 & Mar-17 & Mar-18 & Mar-19 & Mar-20 & Jump \\
\hline Net sales growth (\%) & & & & & & \\
$\quad$ Hyundai Motor India & 18.4 & 11.0 & 6.3 & 19.6 & $(0.7)$ & $(19.1)$ \\
$\quad$ Tata Motors & 19.6 & 3.1 & 31.6 & 19.7 & $(36.8)$ & $(56.4)$ \\
EBITDA growth (\%) & & & & & & \\
$\quad$ Hyundai Motor India & 24.7 & 32.8 & 4.6 & 9.9 & $(10.5)$ & $(35.2)$ \\
$\quad$ Tata Motors & 181.1 & $(45.1)$ & 180.4 & 38.1 & $(95.6)$ & $(276.7)$ \\
Net profit margins (\%) & & & & & & \\
$\quad$ Hyundai Motor India & 4.0 & 5.5 & 5.6 & 5.7 & 5.2 & 1.2 \\
$\quad$ Tata Motors & $(0.1)$ & $(5.6)$ & $(1.8)$ & 8.3 & $(16.4)$ & $(16.3)$ \\
RoCE (\%) & & & & & & \\
$\quad$ Hyundai Motor India & 24.1 & 33.5 & 30.4 & 30.9 & 24.4 & 0.3 \\
$\quad$ Tata Motors & 5.1 & $(2.6)$ & 2.5 & 13.0 & $(15.0)$ & $(20.1)$ \\
Assets turnover ratio (Times) & & & & & & \\
$\quad$ Hyundai Motor India & 2.5 & 3.4 & 4.8 & 4.9 & 3.9 & 1.4 \\
$\quad$ Tata Motors & 1.5 & 1.4 & 1.7 & 1.9 & 1.1 & $(0.4)$ \\
\hline
\end{tabular}

Source: CRISIL research

Supplementary Information The online version contains supplementary material available at https://doi.org/10.1007/s42943-021-00029-5.

Acknowledgements I am thankful to all the automobile industry experts for sharing their valuable inputs through informal and structured interactions, which helped in building up the case effectively. I want to acknowledge and thank all the anonymous reviewers, the editors of JGBC, and the Editor-in-Chief, Dr. Kirankumar S. Momaya, for their valuable comments and suggestions that significantly improved this article. I would also like to thank the members and associates of the Group on Competitiveness, IIT Bombay, especially Dr. Ajitabh Ambastha and Padmanav Adhikari, for their support and guidance. Thanks to all the faculty members and fellow researchers of Shailesh J. Mehta School of Management, IIT Bombay, and TA and fellow learners of Competitiveness courses, particularly Resham Khade, for their support and help during the research based on the course project.

Funding The author did not receive any funding support from any organization for the submitted work.

\section{Declarations}

Conflict of interest The author declared no potential conflicts of interest concerning the research, authorship, and publication of this article.

\section{References}

Alagappan, B. C., Sahu, S., \& Sahney, S. (2013). Marketing competitiveness: a case on launch of TATA nano. International Journal of Global Business and Competitiveness, 8(1), 39-51.

Ambastha, A., \& Momaya, K. (2004). Framework for competitiveness. Singapore Management Review, 26(1), 45-61.

Bannasch, F., Rossi, G., Thaidigsmann, B. (2017). Push toward platforms and modularity: Choosing the right product development organization design. 1-7. Available at https://www.mckinsey.com/ business-functions/operations/our-insights/platforms-and-modul arity-setup-for-success. Accessed 18 Feb 2021.

Barney, J. B. (1991). Firm resources and sustained competitive advantage. Journal of Management, 17(1), 99-120. https://doi.org/10. 1177/014920639101700108.

Becker, M. C., \& Zirpoli, F. (2003). Organizing new product development: knowledge hollowing-out and knowledge integration - the FIAT auto case. International Journal of Operations \& Production Management, 23(9), 1033-1061. https://doi.org/10.1108/ 01443570310491765

Becker-Ritterspach, F., \& Bruche, G. (2012). Capability creation and internationalization with business group embeddedness - the case of Tata Motors in passenger cars. European Management Journal, 30(3), 232-247. https://doi.org/10.1016/j.emj.2012.03.009.

Bloomberg, Q. (2021). Auto sales in december 2020: eicher sales rise $37 \%$, Tata Motors' passenger vehicle sales nearly double.

Bodhanwala, S., \& Bodhanwala, R. (2020). Tata Motors: Can the turnaround plan improve performance? https://www.iveycases.com/ ProductView.aspx ?id=107468. Accessed 8 Mar 2021.

Bruche, G. (2010). Tata Motor's transformational resource acquisition path: A case study of latecomer catch-up in a business group context (No. 55). Working Papers of the Institute of Management Berlin at the Berlin School of Economics and Law (HWR Berlin).

Castanias, R. P., \& Helfat, C. E. (1991). Managerial resources and rents. Journal of Management, 17(1), 155-171. https://doi.org/ 10.1177/014920639101700110.

Cusumano, M. A., \& Gawer, A. (2002). The elements of platform leadership. MIT Sloan Management Review, 43, 51-58.

D'Cruz, J., \& Rugman, A. (1992). New Concepts for Canadian Competitiveness. Kodak.

Dhingra, M. (2020). Over 1,900 bookings made via Hyundai's Click to Buy. https://www.autocarindia.com/car-news/over-1900-booki ngs-made-via-hyundais-click-to-buy-417893. Accessed 12 Feb 2021.

E.T. Auto. (2018). India has 22 cars per 1,000 individuals: Amitabh Kant. E.T. Auto. Available at https://auto.economictimes.india times.com/news/passenger-vehicle/cars/india-has-22-cars-per1000-individuals-amitabh-kant/67059021. Accessed 18 Feb 2021.

Freyssenet, M. (2009). The Second Automobile Revolution, Trajectories of the World Car makers in the 21st Century. Palgrave Macmillan. 
Haugh, D., Mourougane, A., \& Chatal, O. (2010). The Automobile Industry in and beyond the Crisis. OECD Economics Department Working Papers. OECD Publishing.

Hyundai Motors. (2018). Investor presentation. https://www.hyund ai.com/content/hyundai/ww/data/ir/calendar/2018/0000000203/ files/hmc-ir-pt-may-2018.pdf. Accessed 20 Feb 2021.

Hyundai Motors press (2020). Available at https://www.hyundai.com/ in/en/hyundai-story/media-center/india-news.html\#itemView. Accessed 12 Apr 2021.

ICCT. (2020). https://theicct.org/publications/fuel-consumption-pvindia-052020. Accessed 10 Mar 2021.

India Brand Equity Foundation. (2021). Automobile Industry in India. Available at https://www.ibef.org/industry/india-automobiles. aspx. Accessed 10 Mar 2021.

India Brand Equity Foundation. (2008). Available at https://www.ibef. org/download/Automotive_010709.pdf. Accessed 10 Mar 2021.

Invest India. (2020). Running in the top gear. https://www.investindia.gov.in/sector/automobile. Accessed 12 Feb 2021.

Kalogerakis, K., Fischer, L., \& Tiwari, R. (2017). A Comparison of German and Indian innovation pathways in the auto component industry. Working paper, Institute for Technology and Innovation Management, Hamburg University of Technology, Hamburg, October. https://doi.org/10.15480/882.1633.

Kumar, S. R., \& Bala Subrahmanya, M. H. (2010). Influence of subcontracting on innovation and economic performance of SMEs in Indian automobile industry. Technovation, 30(11-12), 558569. https://doi.org/10.1016/j.technovation.2010.06.005.

Lampón, J. F., Cabanelas, P., \& González-Benito, J. (2017). The impact of modular platforms on automobile manufacturing networks. Production Planning and Control, 28(4), 335-348. https://doi.org/10.1080/09537287.2017.1287442.

Lampón, J. F., Frigant, V., \& Cabanelas, P. (2019). Determinants in the adoption of new automobile modular platforms: What lies behind their success? Journal of Manufacturing Technology Management, 30(4), 707-728. https://doi.org/10.1108/ JMTM-07-2018-0214.

Loganathan, Y. D. (2013). Contemporary tools and approach for project management sustainability in Indian automotive industry Nos 01-1278 (pp. 1-12). SAE International. https://doi.org/ 10.4271/2013-01-1278.

Meyer, M. H., \& Lehnerd, A. P. (1997). The Power of Product Platforms. The Free Press.

MHIPE. (2012). Report of Working Group on Automotive Sector for the 12th Five Year Plan. Ministry of Heavy Industries \& Public Enterprises, Government of India, available at: https:// dhi.nic.in/writereaddata/Auto\%20report\%20final.pdf. Accessed 14 Feb 2021

Momaya, K. S. (2001). International Competitiveness: Evaluation and Enhancement. Hindustan Publishing Corporation.

Momaya (2008). Management of Technology and Innovation (MoT) for Competitiveness: Diagnosing Problems at Vonda Motors, ET Cases, No. STG-1-0058, pp. 1-9; Reference no.318-0001-1, last accessed on March 2, 2021 at https://www.thecasecentre.org.

Momaya, K. (2009). Exploring cooperative strategies for innovation: case of biopharmaceutical firms from India and Japan. The Journal of Science Policy and Research Management, 23(4), 327-338. https://doi.org/10.20801/jsrpim.23.4_327.

Momaya, K. S. (2018). Management of Technology and Innovation (MoT) for Competitiveness: Diagnosing Problems at Vonda Motors, Case Reference no. 318-0001-1. https://www.theca secentre.org/main/products/view?id=149299. Accessed May 31 .

Momaya, K. S. (2019). The past and the future of competitiveness research: a review in an emerging context of innovation and EMNEs. International Journal of Global Business and Competitiveness, 14(1), 1-10. https://doi.org/10.1007/ s42943-019-00002-3.
Momaya, K. S., Bhat, S., \& Lalwani, L. (2016). Institutional growth and industrial competitiveness: exploring the role of strategic flexibility taking the case of select institutes in India. Global Journal of Flexible Systems Management, 11(2), 111-122. https://doi.org/10.1007/s40171-016-0144-2.

Moon, H. C., Lee, Y. W., \& Yin, W. (2015). A new approach to analysing the growth strategy of business groups in developing countries: the case study of India's Tata Group. International Journal of Global Business and Competitiveness, 10(1), 1-15.

Nauhria, Y., Kulkarni, M. S., \& Pandey, S. (2018). Development of strategic value chain framework for Indian car manufacturing industry. Global Journal of Flexible Systems Management, 19(1), 21-40. https://doi.org/10.1007/s40171-017-0179-z.

Nauhria, Y., Pandey, S., \& Kulkarni, M. S. (2011). Competitive priorities for Indian car manufacturing industry (2011-2020) for global competitiveness. Global Journal of Flexible Systems Management, 12(3 \& 4), 21-32. https://doi.org/10.1007/BF033 96603.

Pahurkar, R. N., \& Metha, P. (2017). Developing sustainable marketing strategy for electric vehicle (EV) - automotif. International Journal of Emerging Research in Management \& Technology, 6(11), 115-129. https://doi.org/10.23956/ijermt.v6i11.54.

Pillania, R. K. (2008). Creation and categorization of knowledge in automotive components SMEs in India. Management Decisions, 46(10), 1452-1464. https://doi.org/10.1108/0025174081 0919986.

Rugraff, E. (2012). The new competitive advantage of automobile manufacturers. Journal of Strategy and Management, 5(4), 407-419. https://doi.org/10.1108/17554251211276371.

Saad, M., \& Patel, B. (2006). An investigation of supply chain performance measurement in the Indian automotive sector. Benchmarking an International Journal, 13(1/2), 36-53. https://doi. org/10.1108/14635770610644565.

Sahoo, T., Banwet, D. K., \& Momaya, K. (2011). Strategic technology management in practice: SAP-LAP hills analysis of an automobile manufacturer in India. International Journal of Business Excellence, 4(5), 519-543. https://doi.org/10.1504/ IJBEX.2011.042156.

Scavarda, L. F., Schaffer, J., Scavarda, A. J., Reia, A. C., \& Schleich, H. (2009). Product variety: an auto industry analysis and a benchmarking study. Benchmarking an International Journal, 16(3), 387-400. https://doi.org/10.1108/14635770910961399.

Seyoum, B., \& Lian, Y. (2018). Market performance implications of modularization: evidence from global auto firms operating in China. International Business Review, 27(1), 852-866. https:// doi.org/10.1016/j.ibusrev.2018.01.008.

Singh, R. K., Garg, S. K., \& Deshmukh, G. S. (2007). Strategy development for competitiveness: a study on Indian auto component sector. International Journal of Productivity and Performance Management, 56(4), 285-304. https://doi.org/10.1108/17410 400710745315.

Sushil, S. (2009). SAP-LAP linkages - a generic interpretive framework for analyzing managerial contexts. Global Journal of Flexible Systems Management, 10(2), 11-20. https://doi.org/ 10.1007/BF03396558.

Sushil, S., \& Garg, S. (2019). Internationalization of Tata Motors: strategic analysis using flowing stream strategy process. International Journal of Global Business and Competitiveness, 14(1), 54-70. https://doi.org/10.1007/s42943-019-00006-z.

Tambade, H., Singh, R. K., \& Modgil, S. (2019). Identification and evaluation of determinants of competitiveness in the Indian auto- component industry. Benchmarking an International Journal, 26(3), 922-950. https://doi.org/10.1108/BIJ-09-2017-0260.

Tata Motors Annual report. (2020). Tata Motors Limited. Accessed 20 Mar 2021 
Tata Review. (2020). Report available at https://www.tatamotors. com/wp-content/uploads/2020/11/05114223/media-01oct20. pdf. Accessed 25 Feb 2021.

Tata Motors Website (2021). Available at https://www.tatamotors.com/ about-us/company-profile/. Accessed 15 Mar 2021.

Tata Motors annual analyst engagement report. (2021). Available at https://www.tatamotors.com/wp-content/uploads/2021/02/22133 316/Tata-Motors-Group-Investor-Day_India-Business-2021.pdf. Accessed 24 Apr 2021.

Tata Motors Press. (2020). Tata Motors launches' Click to Drive' - a contactless sales platform. Available at https://www.tatam otors.com/press/tata-motors-launches-click-to-drive-a-conta ctless-sales-platform/. Accessed 20 Feb 2021.

Taumar, D. (2017). Every car made by Tata Motors is losing money: N Chandrasekaran. https://auto.economictimes.indiatimes.com/ news/industry/every-single-car-is-losing-money-at-tata-motorsn-chandrasekaran/61004017. Accessed 25 Mar 2021.

Umamaheswari, R., \& Momaya, K. (2008). Role of creative marketing in $10 \mathrm{X}$ journey: case of I.T. Firms from India. IIMB Management Review, 20(1), 113-130.

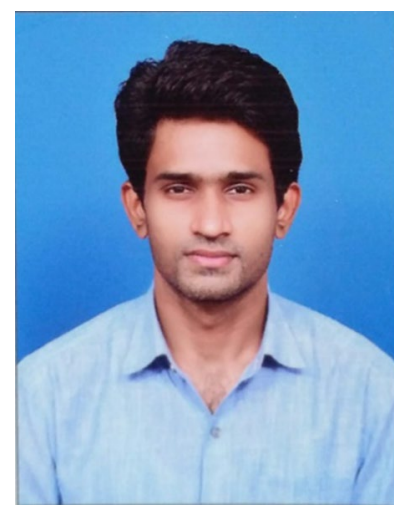

Shivakumar S. Malagihal is a research scholar at Shailesh J. Mehta School of Management, IIT Bombay. He is a member of the Group on Competitiveness (GoC) and actively contributes to growing activities. His research interests include international competitiveness and digital platforms. Shivakumar has presented papers at various international conferences such as the 19th GLOGIFT - hosted by IIT Roorkee and 29th IAMOT hosted by Nile University, Cairo, Egypt. He has 8 years of diverse experience in technology, consulting, and academics, and he is a life member of the growing professional society GIFT. 